\title{
PENGARUH OPINI AUDIT DAN TEMUAN AUDIT TERHADAP TINGKAT KORUPSI (STUDI PADA PEMERINTAH DAERAH DI INDONESIA TAHUN 2017)
}

ABSTRACT: This study aims to investigate the effect of audit opinion and audit findings on the level of corruption in the Regional Government in Indonesia in 2017. The object in this study is the local government included in the Public Integrity Survey conducted by the Corruption Eradication Commission in 2017. The sampling technique used in this study was saturated sampling with a total sample of 19 local government institutions. The method used in this analysis is multiple linear regression using IBM SPSS 25. Based on the results of the test the significance of audit opinions and audit findings simultaneously evaluating the level of corruption. Partially, audit opinion variables and negative audit findings on the level of corruption.

\author{
Riri Safira Syahrir, Elly \\ Suryani \\ Prodi S1 Akuntansi, Fakultas \\ Ekonomi dan Bisnis, \\ Universitas Telkom
}

Keywords: Corruption, level of corruption, audit opinion, audit findings

Kata Kunci: Korupsi, tingkat korupsi, opini audit, temuan audit
ABSTRAK: Penelitian ini bertujuan untuk melakukan investigasi terhadap pengaruh opini audit dan temuan audit terhadap tingkat korupsi pada Pemerintah Daerah di Indonesia pada tahun 2017. Objek dalam penelitian ini adalah pemerintah daerah yang masuk dalam Survei Integritas Publik yang dilakukan oleh Komisi Pemberantasan Korupsi (KPK) pada tahun 2017. Teknik sampling yang digunakan dalam penelitian ini adalah sampling jenuh dengan jumlah sampel sebanyak 19 instansi pemerintah daerah. Metode yang digunakan dalam analisis ini adalah regresi linier berganda dengan menggunakan IBM SPSS 25. Berdasarkan hasil uji signifikansi opini audit dan temuan audit secara simultan berpengaruh terhadap tingkat korupsi. Secara parsial, variabel opini audit dan temuan audit berpengaruh negatif terhadap tingkat

korupsi.

\section{Pendahuluan}

Korupsi di Indonesia dimulai sejak era Orde Lama sekitar tahun 1960-an bahkan sangat mungkin telah terjadi pada tahuntahun sebelumnya. Namun korupsi di Indonesia semakin banyak sejak akhir 1997 saat negara mengalami krisis politik, sosial, kepemimpinan, dan kepercayaan yang pada akhirnya menjadi krisis multidimensi. Menurut Undang-Undang Nomor 31 Tahun 1999 tentang Pemberantasan Tindak Pidana Korupsi mengartikan bahwa korupsi adalah setiap orang yang dikategorikan melawan hukum, melakukan perbuatan memperkaya diri sendiri, menguntungkan diri sendiri atau orang lain atau suatu korporasi, menyalahgunakan kewenangan maupun kesempatan atau sarana yang ada padanya karena jabatan atau kedudukan yang dapat merugikan keuangan negara atau perekonomian negara. Penelitian ini dilakukan pada intansi pemerintah daerah yang masuk dalam Survei Integritas Sektor Publik Komisi Pemberantasan Korupsi (KPK) pada tahun 2017, karena menurut salah satu fenomena yaitu adanya kasus korupsi pada tahun 2017 dengan nilai kerugian negara paling besar di Jawa Barat adalah kasus dugaan korupsi pencairan kredit fiktif di Bank Jabar (BJB) Syariah yang melibatkan Yocie Gusman selaku Plt Dirut BJB Syariah dengan menimbulkan kerugian negara sekitar Rp 628 miliar (ICW,2017). Dapat disimpulkan bahwa otonomi daerah 
menjadi salah satu faktor terjadinya korupsi pada pemerintah daerah yang akan menyebabkan penurunan citra dan nilai pemerintah daerah di mata masyarakat. Berdasarkan hasil dari penelitian sebelumnya terdapat beberapa faktor yang berpengaruh terhadap tingkat korupsi yaitu opini audit dan temuan audit.

Opini audit merupakan kesimpulan kewajaran atas informasi yang telah diaudit. Dikatakan wajar dibidang auditing apabila bebas dari keraguan-keraguan dan ketidakjujuran (free from bias and dishonesty), dan lengkap informasinya (full disclosure), (Halim, 2015). Penelitian yang dilakukan oleh Masyitoh et al. (2015) menyatakan bahwa opini audit berpengaruh terhadap persepsi korupsi pemerintah daerah, menurut penelitian tersebut pemerintah daerah yang memperoleh opini tidak memberikan pendapat dari auditor memiliki persepsi korupsi yang secara signifikan lebih tinggi dibanding pemerintah daerah yang memperoleh opini wajar.

Menurut Standar Pemeriksaan Keuangan Negara (SKPN) yang disusun oleh BPK temuan audit adalah temuan atas pengendalian intern, temuan atas ketaatan terhadap peraturan perundangan dan temuan kecurangan dan ketidakpatuhan, yang selanjutnya dilaporkan dalam laporan hasil pemeriksaan. Berdasarkan penelitian dari Huefner (2011) menyatakan bahwa temuan audit sistem pengendalian internal dapat digunakan untuk mendeteksi adanya potensi kecurangan pemerintah daerah.

Telah terbukti bahwa variabelvariabel ini memiliki pengaruh terhadap tingkat korupsi, tetapi masih didapatkan inkonsistensi dengan penelitian

-penelitian sebelumnya. Oleh karena itu, peneliti bermaksud mengetahui apakah terdapat pengaruh antara opini audit dan temuan audit terhadap tingkat korupsi pada pemerintah daerah tahun 2017.
Korupsi umumnya didefinisikan sebagai keuntungan pribadi. Korupsi yang didefinisikan seperti itu meliputi, misalnya, penjualan kekayaan negara secara tidak sah oleh pejabat, kickbacks dalam pengadaan di sektor pemerintahan, penyuapan, dan "pencurian" (embezzlement) dana-dana pemerintah (Tuanakotta, 2010).

Menurut Santoso et al. (2014:27), secara umum, beberapa faktor penyebab maraknya korupsi antara lain adalah penegakan hukum yang lemah, administrasi birokrasi yang membuka peluang korupsi,

gaji rendah, kesenjangan gaji, rendahnya etika dan moralitas.

Menurut Alfitra (2014), dampak korupsi yang paling utama adalah runtuhnya akhlak, moral, integritas, dan religiusitas bangsa. Kedua, adanya efek buruk bagi perekonomian negara. Ketiga, korupsi juga memberikan kontribusi bagi matinya etos kerja masyarakat. Keempat, terjadinya eksploitasi sumber daya alam oleh segelintir orang. Kebijakan investasi yang diambil pemerintah dalam suasana penuh korupsi menyebabkan tidak meratanya kesempatan pengelolaan sumber daya alam.

\subsection{Opini Audit}

Menurut Undang Undang Nomor 15

Tahun 2004 opini merupakan penyataan profesional pemeriksaan mengenai kewajaran informasi keuangan yang disajikan dalam laporan keuangan yang didasarkan pada kriteria (i) kesesuaian dengan Standar Akuntansi Pemerintah, (ii) kecukupan pengungkapan, (iii) kepatuhan terhadap peraturan perundang-undangan dan (iv) efektivitas sistem pengendalian intern.

Menurut Hery (2017) sebagai tahap akhir dari keseluruhan proses audit, sangatlah penting dalam setiap penugasan untuk mengkomunikasikan berbagai hasil temuan auditor eksternal. Auditor akan bertanggung jawab apabila laporan audit yang diterbitkannya tidaklah tepat.

\section{Pengembangan Hipotesis 2.1 Tingkat Korupsi}


1. Laporan audit wajar tanpa pengecualian Laporan audit standar wajar tanpa pengecualian apabila semua kondisi audit telah terpenuhi dan tidak ada salah saji yang signifikan serta laporan keuangan telah disajikan secara wajar sesuai dengan standar akuntansi.

2. Laporan audit wajar tanpa pengecualian dengan paragraf penjelas

Laporan audit wajar tanpa pengecualian dengan paragraf penjelasan atau modifikasi kata-kata, dimana laporan keuangan telah disajikan secara wajar, tetapi auditor merasa perlu atau wajib untuk memberikan informasi tambahan.

3. Laporan pendapat wajar dengan pengecualian

Laporan pendapat wajar dengan pengecualian diterbitkan apabila auditor yakin bahwa laporan keuangan secara keseluruhan telah disajikan secara wajar, tetapi terdapat pembatasan dalam ruang lingkup audit atau kelalaian dalam mematuhi standar akuntansi.

4. Laporan pendapat tidak wajar

Laporan pendapat tidak wajar diterbitkan hanya apabila auditor yakin bahwa laporan keuangan secara keseluruhan mengandung salah saji yang sangat material atau sangat menyesatkan sehingga tidak menyajikan secara wajar posisi keuangan atau hasil operasi dan arus kas sesuai dengan standar akuntansi.

5. Laporan menolak memberikan pendapat Laporan menolak memberikan pendapat diterbitkan apabila auditor tidak dapat meyakinkan dirinya sendiri bahwa laporan keuangan klien secara keseluruhan telah disajikan secara wajar.

\subsection{Temuan Audit}

Menurut BPK (2017) dalam Standar Pemeriksaan Keuangan Negara (SKPN) temuan audit berupa temuan atas pengendalian intern, temuan atas ketaatan terhadap peraturan perundangan dan temuan kecurangan dan ketidakpatuhan. Hal ini harus disajikan menurut elemen temuan yang terdiri dari kriteria, kondisi, sebab dan akibat.

Hasil pemeriksaan BPK atas Laporan

Keuangan Pemerintah Daerah (LKPD) ditemukan kelemahan Sistem Pengendalian
Internal (SPI) yang terdiri atas permasalahan kelemahan sistem pengendalian akuntansi dan pelaporan, permasalahan kelemahan sistem pengendalian pelaksanaan anggaran pendapatan dan belanja, dan permasalahan kelemahan struktur pengendalian intern. Selain permasalahan kelemahan SPI, hasil pemeriksaan BPK juga mengungkapkan permasalahan ketidakpatuhan terhadap ketentuan peraturan perundang-undangan. Permasalahan tersebut meliputi permasalahan ketidakpatuhan yang dapat mengakibatkan kerugian, potensi kerugian, dan kekurangan penerimaan (berdampak finansial), serta penyimpangan administrasi (tidak berdampak finansial) (BPK,2018).

\subsection{Kerangka Penelitian \\ 2.4.1 Pengaruh Opini Audit terhadap Tingkat Korupsi}

Opini audit merupakan kesimpulan kewajaran atas informasi yang telah diaudit. Dikatakan wajar dibidang auditing apabila bebas dari keraguan-keraguan dan ketidakjujuran (free from bias and dishonesty), dan lengkap informasinya (full disclosure). Hal ini tentu saja masih dibatasi oleh konsep materialitas (Halim, 2015). Opini yang wajar tanpa pengecualian yang dapat diperoleh pemerintah daerah dari BPK dapat mencerminkan suatu pemerintah yang tertata dan patuh terhadap peraturan dan perundang-undangan serta pengendalian internal yang baik. Sehingga apabila suatu pemerintah daerah dapat menyajikan laporan keuangan dengan opini wajar tanpa pengecualian maka semakin rendah tingkat korupsi yang terjadi dalam pemerintah daerah tersebut. Penelitian yang dilakukan oleh Masyitoh et al. (2015) menyatakan bahwa opini audit berpengaruh terhadap persepsi korupsi pemerintah daerah, menurut penelitian tersebut pemerintah daerah yang memperoleh pernyataan tidak memberikan pendapat dari auditor memiliki persepsi korupsi yang secara signifikan lebih tinggi dibanding pemerintah daerah yang memperoleh opini wajar.

\subsubsection{Pengaruh Temuan Audit terhadap Tingkat Korupsi}


Menurut Standar Pemeriksaan Keuangan Negara (BPK,2017) temuan audit berupa temuan atas pengendalian intern, temuan atas ketaatan terhadap peraturan perundangan dan temuan kecurangan dan ketidakpatuhan selanjutnya harus disajikan menurut elemen temuan yang terdiri dari kriteria, kondisi, sebab dan akibat. Huefner (2011) menjelaskan bahwa cara utama dalam mencegah terjadinya kecurangan yaitu

oleh Liu dan Lin (2012) yang menyatakan bahwa tingkat korupsi di Provinsi China dipengaruhi oleh temuan audit.

\subsection{Hipotesis Penelitian}

$\mathrm{H}_{1}$ : Opini audit dan temuan audit secara simultan berpengaruh signifikan terhadap tingkat korupsi.

$\mathrm{H}_{2}$ : Opini audit secara parsial berpengaruh negatif terhadap tingkat korupsi.

$\mathrm{H}_{3}$ : Temuan audit secara parsial berpengaruh positif terhadap tingkat korupsi.

\section{Metode, Data dan Analisis}

Metode analisis yang digunakan untuk menguji hipotesis pada penelitian ini adalah regresi berganda (multiple regression). Regresi berganda yaitu alat yang dapat digunakan untuk memprediksi permintaan dimasa akan datang berdasarkan data masa lalu atau untuk mengetahui pengaruh satu atau lebih variabel bebas (independeff) terhadap satu variabel tak bebas (Sugiyondin 2015:2). Penelitian ini menggunakan dsłd. variabel independen, yaitu opini audit dRev temuan audit serta tingkat korupsi sebagai variabel dependen. Persamaan regresi berganda dalam penelitian ini adalah sebagai berikut:

Y $=\alpha-\beta_{1}$ OPINION $+\beta_{2}$ FINDING $+\varepsilon$

Dimana:

\begin{tabular}{|c|c|}
\hline Y & $=$ Tingkat korupsi \\
\hline OPINION & $=$ Opini audit \\
\hline FINDING & $=$ Temuan audit \\
\hline$\alpha$ & $=$ Konstanta \\
\hline
\end{tabular}

dengan sistem pengendalian yang kuat sehingga semakin banyak temuan audit akan meningkatkan kemungkinan terjadinya korupsi. Beberapa penelitian menunjukkan bahwa terdapat keterikatan antara temuan audit terhadap tingkat korupsi. Penelitian Yuliana dan Setyaningrum (2016) menunjukkan bahwa temuan audit berpengaruh positif terhadap persepsi korupsi, sama halnya dengan penelitian $\beta_{1}, \beta_{2} \quad=$ Koefisien regresi masingmasing variabel

\section{Hasil dan Diskusi}

\subsection{Analisis Statistik Deskriptif}

Berdasarkan Tabel 1 variabel tingkat korupsi yang diukur dengan indeks integritas publik dan di survei oleh KPK pada tahun 2017 memiliki nilai rata-rata (mean) sebesar 3,5296 dengan nilai standar deviasi sebesar 0,6349 . Nilai maksimum dari rasio tingkat korupsi pada tahun 2017 adalah sebesar 4,709 yang dimiliki oleh Pemerintah Provinsi Papua. Sedangkan nilai minimum dari rasio tingkat korupsi pada tahun 2017 adalah sebesar 2,285 yang dimiliki oleh Pemerintah Kabupaten Badung.

Tabel 1. Uji Statistik Deskriptif

\begin{tabular}{lrrr} 
Kingkat & \multicolumn{1}{c}{$\begin{array}{c}\text { Opini } \\
\text { Audit }\end{array}$} & \multicolumn{1}{c}{$\begin{array}{c}\text { Temuan } \\
\text { Audit }\end{array}$} \\
\hline Tean & 3,5296 & 4,7895 & 2,0526 \\
Gin & 4,709 & 5 & 3 \\
ax & 2,285 & 3 & 1
\end{tabular}

Sumber: Diolah oleh penulis (2019)

Berdasarkan Tabel 1 variabel opini audit yang diukur dengan skala interval satu sampai lima memiliki nilai rata-rata (mean) sebesar 4,7895 dengan nilai standar deviasi sebesar 0,6306. Terdapat 17 pemerintah daerah yang mendapatkan opini wajar tanpa pengecualian dan 2 yang mendapatkan opini selain wajar tanpa pengecualian. Pemerintah Kabupaten Klaten dan Pemerintah Provinsi Maluku Utara mendapatkan opini wajar dengan pengecualian. 
Berdasarkan Tabel 1 variabel temuan audit yang diukur dengan skala interval satu sampai tiga memiliki nilai rata-rata (mean) sebesar 2,0526 dengan nilai standar deviasi sebesar 1,0260. Pemerintah daerah yang memiliki temuan kasus paling tinggi pada 4.2 Uji Asumsi Klasik

Tabel 2 menunjukkan bahwa hasil pengujian statistik menggunakan model Kolmogorov-Smirnov dengan nilai signifikansi sebesar 0,2 dimana angka tersebut lebih besar daripada $\alpha=0,05$. Dengan demikian data telah terdistribusi dengan normal.

Tabel 2. Hasil Uji Normalitas

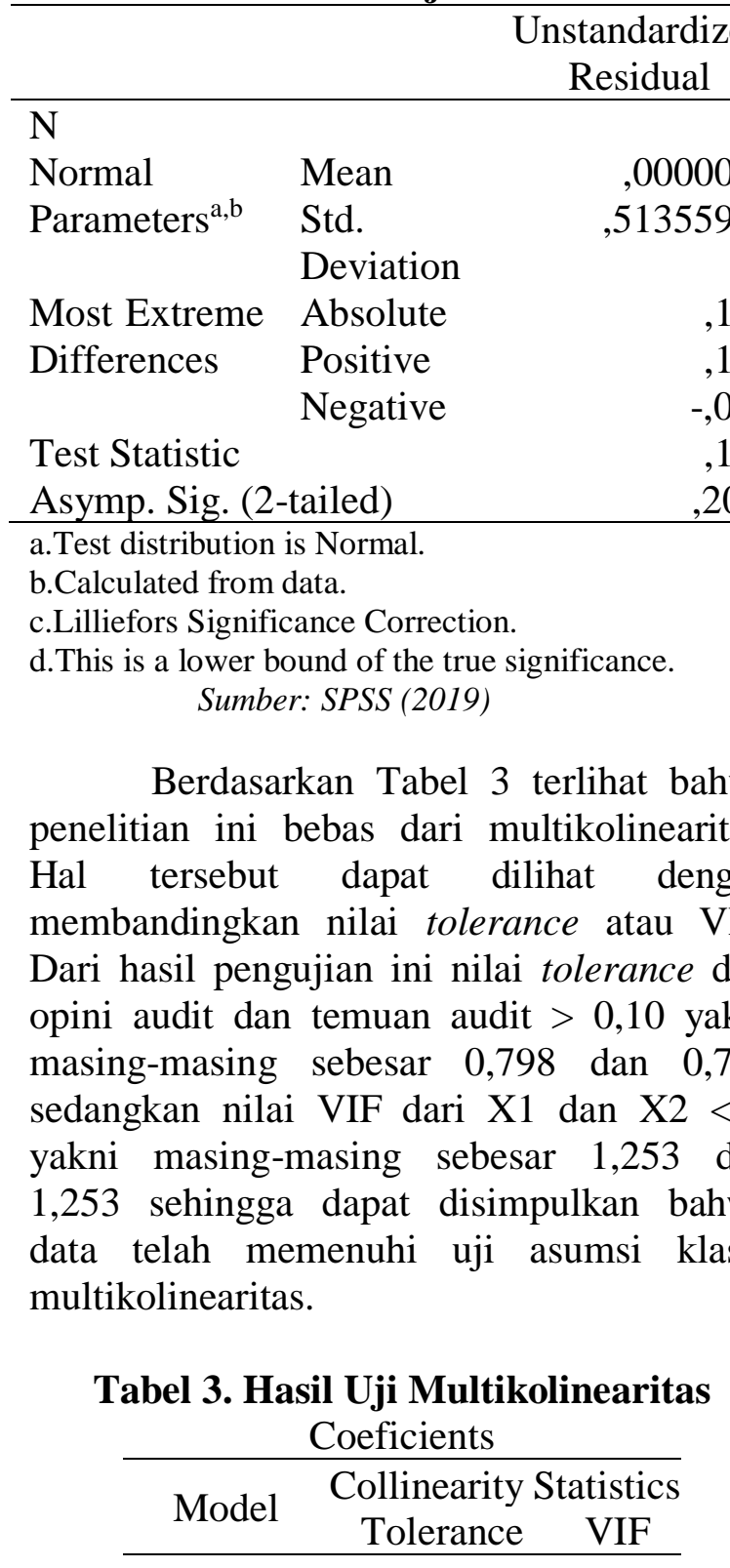
, $200^{\mathrm{c}}$ adalah Pemerintah Provinsi Jawa Barat yaitu sebanyak 161 kasus, sedangkan pemerintah daerah yang memiliki temuan kasus paling rendah adalah Pemerintah Kota Madiun yaitu sebanyak 5 kasus.

\begin{tabular}{ccc}
\hline (Constant) & & \\
1 OPINION &, 798 & 1,253 \\
FINDINGS &, 798 & 1,253 \\
\hline a. Dependent Variable: CORRUPTION
\end{tabular}

Sumber: SPSS (2019)

Berdasarkan Tabel 4 dari hasil uji glejser diperoleh nilai signifikansi X1 dan X2 $>0,05$ yaitu sebesar 0,677 dan 0,516 maka dapat disimpulkan bahwa data telah memenuhi uji asumsi klasik heterokedasitas.

Tabel 4. Hasil Uji Heteroskedastisitas Coefficients

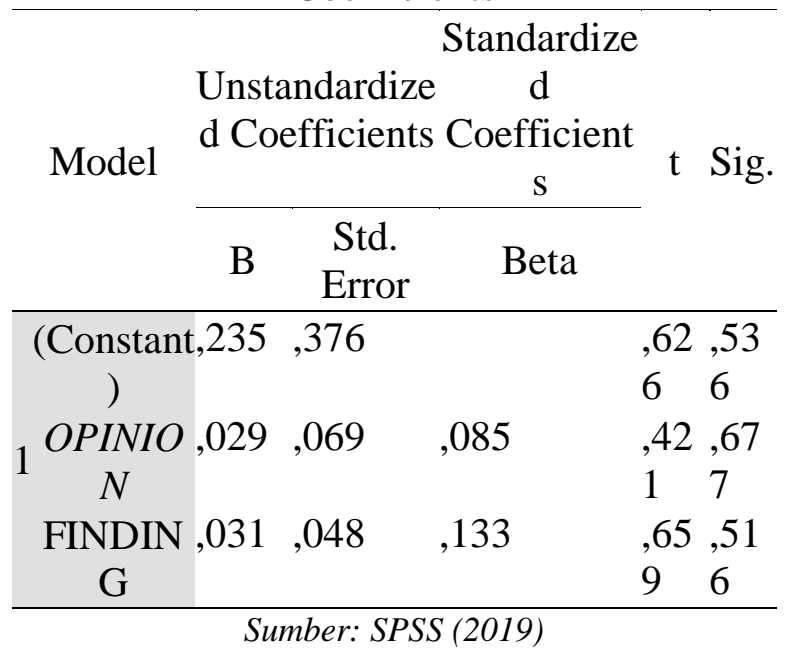

\subsection{Uji Koefisien Determinasi}

Berdasarkan Tabel 5 terlihat nilai koefisien determinasi sebesar $26,4 \%$ dapat memberikan arti bahwa variabel independen yang terdiri dari opini audit dan temuan audit dapat menjelaskan pengaruhnya terhadap tingkat korupsi sebesar $26,4 \%$ sedangkan sisanya $73,6 \%$ dijelaskan oleh variabel lain diluar penelitian ini.

Tabel 5. Model Summary

Model R $\begin{gathered}\mathrm{R} \\ \text { Square }\end{gathered} \begin{gathered}\text { Adjusted R Std. Error of } \\ \text { Square }\end{gathered}$




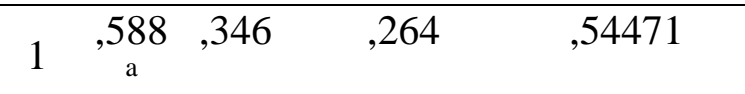

Sumber: SPSS (2019)

\subsection{Pengujian Hipotesis dan Analisis Regresi Linier Berganda Hasil pengujian secara Simultan (Uji F)}

Hasil uji F yang terdapat pada Tabel 6 menunjukkan nilai signifikansi sebesar 0,034 yang lebih kecil daripada 0,05 , sehingga dapat disimpulkan bahwa Ho ditolak dan $\mathrm{Ha}$ diterima, yang artinya opini audit dan temuan audit secara simultan berpengaruh signifikan terhadap tingkat korupsi pada Pemerintah Daerah yang disurvei KPK tahun 2017.

\section{Tabel 6. Hasil Uji F}

\begin{tabular}{|c|c|c|c|}
\hline Model & $\begin{array}{l}\text { Sum of } \\
\text { Squares }\end{array}$ & df $\begin{array}{c}\text { Mean } \\
\text { Square }\end{array}$ & Sig. \\
\hline Regression & 2,508 & 21,254 & $4,226,034^{b}$ \\
\hline 1 Residual & 4,747 & ,297 & \\
\hline Total & 7,255 & 18 & \\
\hline
\end{tabular}

Hasil Pengujian Hipotesis Secara Parsial (Uji T)

Berdasarkan Tabel 7 dalam kolom Unstandarized Coefficient bagian B diperoleh model persamaan regresi berganda yaitu:

\section{$\mathrm{Y}=6,724-0,530 \mathrm{OPINION}$ 0,377FINDINGS $+\varepsilon$}

Adapun penjelasan dari nilai rumus diatas adalah sebagai berikut:

1. Nilai konstanta menunjukkan apabila tidak ada nilai variabel bebas (bernilai konstan) yaitu X1 dan X2 maka nilai dari variabel $Y$ tidak mengalami perubahan atau tetap sebesar 6,724.

2. Koefisien regresi OPINION sebesar 0,530 menunjukkan bahwa setiap terjadi peningkatan variabel opini audit sebesar 1 satuan maka akan menurunkan variabel tingkat korupsi sebesar 0,530 dengan asumsi variabel lain dianggap tetap.

3. Koefisien regresi FINDINGS sebesar 0,377 menunjukkan bahwa setiap terjadi peningkatan variabel temuan audit sebesar 1 satuan maka akan menurunkan variabel tingkat korupsi sebesar 0,377 dengan asumsi variabel lain dianggap tetap.

Tabel 7. Hasil Analisis Regresi Berganda

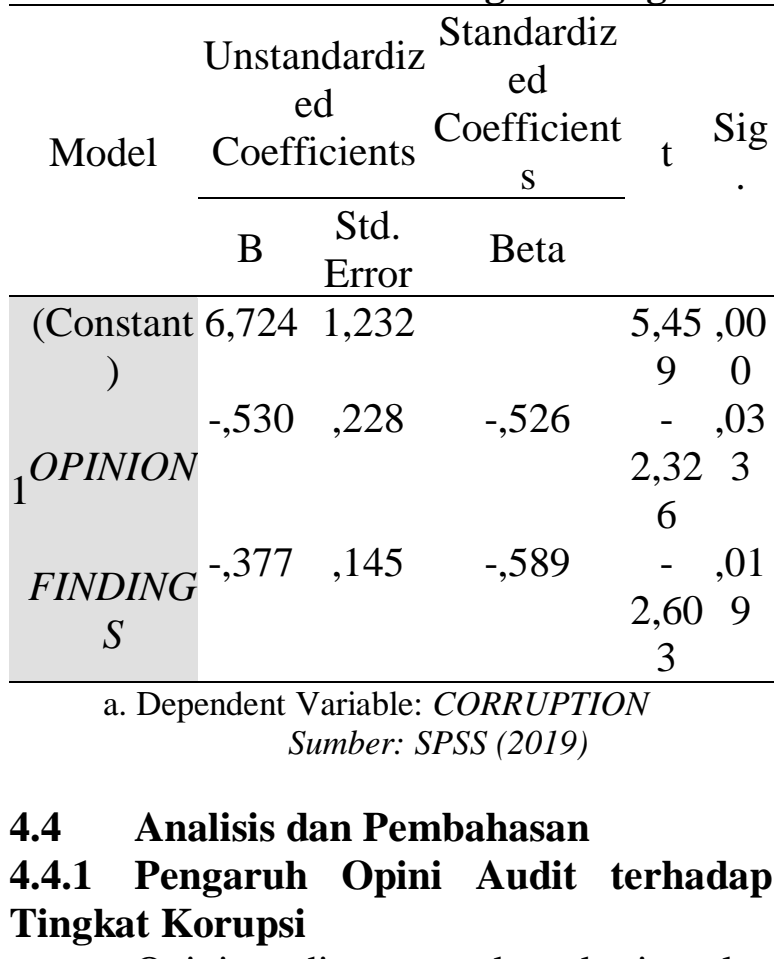

Opini audit merupakan kesimpulan kewajaran atas informasi yang telah diaudit. Dikatakan wajar dibidang auditing apabila bebas dari keraguan-keraguan dan ketidakjujuran (free from bias and dishonesty), dan lengkap informasinya (full disclosure). Hal ini tentu saja masih dibatasi oleh konsep materialitas (Halim, 2015).

Opini Audit memiliki nilai koefisien regresi sebesar $-0,530$ dengan nilai signifikansi 0,033 menunjukkan nilai yang lebih kecil dari $\alpha=0,05$ sehingga $\mathrm{Ha}$ diterima dan Ho ditolak yang berarti variabel opini audit secara parsial memberikan pengaruh negatif terhadap tingkat korupsi pada pemerintah daerah yang disurvei KPK tahun 2017. Dengan kata lain penelitian ini mendukung hasil penelitian M. Faathir Afif (2015) dan Masyitoh et. Al (2015).

Penelitian ini menunjukkan bahwa opini yang didapat oleh pemerintah daerah terdapat hubungan terbalik terhadap tingkat korupsi yaitu semakin banyak opini wajar yang di terima oleh pemerintah daerah maka semakin rendah pula tingkat korupsi pada 
pemerintah daerah. Opini audit merupakan faktor penting yang menjadi tolak ukur dari efektivitas pengawasan dan penilaian kinerja pengelolaan keuangan instansi daerah sehingga tingkat korupsi dapat diminimalisir (Faathir Afif,2015).

Penelitian ini juga membuktikan bahwa semakin banyak opini wajar yang diperoleh pemerintah daerah menunjukkan penilaian kinerja pemerintah daerah yang baik. Kinerja pemerintah daerah yang dinilai baik dapat menunjukkan rendahnya potensi penyimpangan pada pemerintah daerah (Masyitoh et al, 2015).

\subsubsection{Pengaruh Temuan Audit terhadap Tingkat Korupsi}

Temuan audit berupa temuan atas pengendalian intern, temuan atas ketaatan terhadap peraturan perundangan dan temuan kecurangan dan ketidakpatuhan selanjutnya harus disajikan menurut elemen temuan yang terdiri dari kriteria, kondisi, sebab dan akibat (BPK,2017).

Temuan Audit memiliki nilai koefisien regresi sebesar -0,377 dengan nilai signifikansi 0,019 menunjukkan nilai yang lebih besar dari $\alpha=0,05$ sehingga $\mathrm{Ha}$ diterima dan Ho ditolak yang berarti variabel temuan audit secara parsial berpengaruh negatif terhadap tingkat korupsi pada Pemerintah Daerah yang disurvei KPK pada tahun 2017. Dengan kata lain penelitian ini mendukung hasil penelitian Abror dan Haryanto (2014).

Penelitian ini menunjukkan bahwa semakin banyak temuan audit berarti semakin rendah tingkat korupsi yang dilakukan oleh pemerintah daerah. Sehingga pemerintah daerah yang didapatkan banyak temuan auditnya belum tentu melakukan tingkat korupsi karena setiap adanya temuan yang ditemukan oleh pihak audit perlu ditindak lajuti terlebih dahulu untuk lebih jelasnya (Shohib dan Haryanto,2014). Hal ini juga bisa dikarenakan tidak selalu temuan audit berupa korupsi, namun bisa juga hanya berupa kesalahan saji dalam laporan keuangan, dan kelemahan pengendalian internal yang tidak material dan tidak berpotensi terjadinya tindak pidana korupsi.

Dapat dilihat dari Pemerintah Provinsi Jawa Barat yang temuan auditnya ditemukan dengan jumlah terbanyak yang ditemukan oleh BPK dengan jumlah 161, tetapi pada hasil survei penilaian integritas Pemerintah Provinsi Jawa Barat dinyatakan mendapatkan indeks 2,954 yang berarti tingkat korupsi pada pemerintah daerah tersebut adalah rendah karena dibawah ratarata tingkat korupsi yaitu sebesar 3,5296.

\section{Kesimpulan dan Saran \\ 5.1 Kesimpulan}

Berdasarkan hasil penelitian dan pembahasan diperoleh kesimpulan sebagai berikut:

1. Hasil Analisis Deskriptif

a) Pemerintah Daerah yang disurvei KPK tahun 2017 yang memiliki nilai tingkat korupsi diatas rata-rata adalah sebesar $52,63 \%$. Hal ini mengindikasikan bahwa instansi pemerintah daerah sebagian besar belum memiliki capaian yang baik dalam hal pemberantasan korupsi, sehingga masih banyak tindak pidana korupsi yang terjadi pada pemerintah daerah.

b) Opini audit yang didapat oleh pemerintah daerah dari BPK sebesar 56,67\% yang mendapatkan opini wajar tanpa pengecualian. Dengan demikian dapat disimpulkan bahwa sebagian besar Pemerintah Daerah yang disurvei KPK tahun 2017 telah mendapatkan nilai opini yang baik.

c) Jumlah temuan audit yang ditemukan oleh BPK pada Pemerintah Daerah yang disurvei KPK tahun 2017 adalah sebesar $47,36 \%$ dibawah rata-rata dan $52,63 \%$ diatas rata-rata. Dengan demikian dapat dikatakan bahwa masih banyak penyimpangan yang dilakukan Pemerintah Daerah yang disurvei KPK tahun 2017.

2. Variabel opini audit dan temuan audit berpengaruh positif terhadap tingkat korupsi pada Pemerintah Daerah yang disurvei KPK tahun 2017. 
3. Pengaruh secara parsial variabel independen terhadap variabel dependen adalah sebagai berikut:

a) Opini audit memiliki pengaruh negatif dalam terhadap tingkat korupsi.

b) Temuan audit memiliki pengaruh negatif dalam terhadap tingkat korupsi.

\subsection{Saran}

5.2.1 Aspek Teoritis

a) Bagi peneliti selanjutnya disarankan agar menguji kembali variabel-variabel yang tidak berpengaruh dalam penelitian ini dan juga menambahkan variabel lainnya seperti temuan audit yang berelevansi langsung dengan tingkat korupsi, temuan audit yang ditindaklanjuti, transparansi dan anggaran belanja daerah.

b) Disarankan bagi peneliti selanjutanya untuk memperluas objek penelitian dan menambah periode penelitian.

\subsubsection{Aspek Praktis}

\section{Bagi Pemerintah Daerah:}

a) Meningkatkan dan memperhatikan segi pengungkapan dokumen anggaran dan juga dokumen pertanggungjaaban.

b) Meningkatkan sistem pengendalian internal.

c) Tidak melanggar peraturan perundangundangan

d) Menindaklanjuti hasil temuan audit

\section{Bagi BPK:}

a) Diharapkan mempunyai komitmen tinggi untuk para auditor dalam melaksanakan tugas dan wewenang sesuai prosedur audit.

b) Meningkatkan kinerja auditor investigatif dan meningkatkan koordinasi untuk peningkatan kerja kinerja dalam mengaudit.

\section{Bagi KPK:}

a) Melakukan pemetaan kerawanan korupsi yang terjadi pada pemerintah daerah.

b) Meningkatkan koordinasi dan kerjasama dengan lintas instansi seperti Kejaksaan Agung, BPK, BPK dan sebagainya

c) Meningkatkan dan membangun sistem serta mekanisme implementasi whistle blower.

\section{DAFTAR PUSTAKA}

Adhitia, Fitang Budi. 2018. "ICW: Ada Penurunan Tren Korupsi Pada Semester I 2018." idntimes.

Afif, M. Faathir. 2015. "Pengaruh Opini Audit, Temuan Audit Dan Tindak Lanjut Hasil Audit Terhadap Persepsi Korupsi Pada Dinas Pendapatan Daerah (DISPENDA) Kabupaten Jember." Simposium Nasional Akuntansi XIII: 3.

Alfitra. 2014. Modus Operandi Pidana Khusus Di Luar KUHP: Korupsi, Money Laundering, \& Trafficking. Raih Asa Sukses.

Badan Pemeriksa Keuangan Republik Indonesia. 2017. Peraturan Badan Pemeriksa Keuangan Republik Indonesia No.1 Tahun 2017 STANDAR PEMERIKSAAN KEUANGAN NEGARA Peraturan Badan Pemeriksa Keuangan Republik Indonesia No.1 Tahun 2017 STANDAR PEMERIKSAAN KEUANGAN NEGARA.

Halim, Abdul. 2015. Auditing : Dasar-Dasar Audit Laporan Keuangan. Kelima. Yogyakarta: Unit Penerbit dan percetakan STIM YKPN.

Haryanto, Shohib Abror; 2014. "Audit Pemerintah Dan Pengendalian Korupsi: Bukti Dari Data Panel Provinsi Di Indonesia." 3: 367-77.

Hery. 2017. Auditing \& Asurans; Pemeriksaan Akuntansi Berbasis Standar Audit Internasional. Gramedia Widiasarana Indonesia.

Huefner, Ronald J. 2011. "Fraud Risks in Local Government: An Analysis of Audit Findings." Journal of Forencic \& Investigative Accounting 3(3): 111-25.

Liu, Jin, and Bin Lin. 2012. "Government Auditing and Corruption Control: 
Evidence from China's Provincial Panel Data." China Journal of Accounting Research 5(2): 163-86. http://linkinghub.elsevier.com/retrieve/p ii/S1755309112000172.

Masyitoh, Rizki Diyah et al. 2015. "Pengaruh Opini Audit, Temuan Audit, Dan Tindak Lanjut Hasil Audit Terhadap Persepsi Korupsi Pada Pemerintah Daerah Tingkat II Tahun." Simposium Nasional Akuntansi 18 Universitas Sumatera Utara: 1-26.

Santoso, Topo et al. 2011. Panduan Investigasi Dan Penuntutan Dengan Pendekatan Hukum Terpadu. Center for International Forestry Research (CIFOR), Bogor, Indonesia.

Sugiyono. (2015). Metode Penelitian Pendidikan (Pendekatan Kuantitatif, Kualitatif dan $R \& D$ ) (hal. 13). Bandung: Alfabeta.

Tuanakotta, Theodorus M. 2010. Akuntansi Forensik Dan Audit Investigatif. Jakarta: Salemba Empat.

Undang-Undang Nomor 15 Tahun 2004 Tentang Pemeriksaan Dan Tanggung Jawab Keuangan Negara.

Undang-Undang Nomor 31 Tahun 1999 Tentang Pemberantasan Tindak Pidana Korupsi.

Yuliana, Ika, and Dyah Setyaningrum. 2016. "Penerapan E-Goverment Dan Akuntabiltas Terhadap Persepsi Korupsi." Prosiding Simposium Nasional Akuntansi XIX: 1-25. 